УДК 342.951: 61 (477)

DOI https://doi.org/10.32837/pyuv.v2i4(29).457

\author{
О.Л. Сіделковський \\ orcid.org/0000-0002-4139-4478

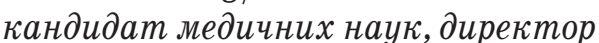 \\ клініки «Аксілед»
}

\title{
КОМУНАЛЬНІ ТА ВІДОМЧІ МЕДИЧНІ ЗАКЛАДИ В СИСТЕМІ ЄДИНОГО МЕДИЧНОГО ПРОСТОРУ: НЕВИРІШЕНІ ПРОБЛЕМИ АДМІНІСТРАТИВНО-ПРАВОВОГО РЕГУЛЮВАННЯ
}

Однією з проблем, що активно обговорюється останнім часом у колах фахівців з охорони здоров'я, медичного права, пересічних громадян, є стан і перспективи розвитку медичної реформи. Про неї дискутують, її побоюються, від неї багато чого очікують. Важливим наразі є питання всебічного дослідження адміністративно-правових засад проведення медичної реформи.

При цьому паралельно вказаним процесам оновлюється саме адміністративне право. За справедливою думкою С.Г. Стеценка, останнім часом у середовищі дослідників-адміністративістів пожвавились дискусії з приводу предмету адміністративного права. Причин такого стану справ $\epsilon$ достатньо багато, спробуємо виокремити ключові:

- модернізація Основного закону держави, котра проявилась внесенням низки змін до Конституції України протягом 2014-2016 років і, як наслідок, певним оновленням конституційного права. Сприймаючи розуміння того, що адміністративне право $€$ «молодшою сестрою» права конституційного, у разі змін всередині «сімейства» вони торкаються всіх, у нашому випадку і адміністративного права;

- постійне виникнення нових суспільних відносин, котрі, у разі наявності в них владного публічно-управлінського складника, потребують унормування за рахунок норм адміністративного права;

- потреби належного урахування євроінтеграційних прагнень нашої держави, котрі, серед іншого, мають проявлятись і модернізацією вітчизняного адміністративного законодавства, адміністративно-правового простору загалом [1, с. 29-30].

Своєю чергою питанням, що характеризується особливою актуальністю у межах медичної реформи, є запровадження та належне функціонування єдиного медичного простору - феномену, який потенційно здатен покращити стан справ із доступністю медичної допомоги. Ми свого часу зазначали, що дослідження проблематики адміністративно-правового забезпечення єдиного медичного простору є досить важливим з таких причин:

1. Наявність наразі нормативно-визначеного поділу системи охорони здоров'я на державну, комунальну та приватну, що, за умови впровадження єдиного медичного простору, зумовлює певну уніфікацію діяльності відповідних медичних закладів.

2. Поєднання необхідності формування єдиного медичного простору з проведенням у нашій державі протягом 2016-2019 pр. медичної реформи, яка передовсім спрямована на зміну системи фінансування медичної галузі.

3. Євроінтеграційні прагнення нашої держави не можуть не бути враховані під час побудови єдиного медичного простору України. Якщо публічна політика нашої держави вже не один рік будується з урахуванням потенційного вступу Україи до Європейського Союзу, то ми маємо ураховувати цей факт під час пошуку шляхів удосконалення правового регулювання медичної діяльності [2, с. 123-124].

Досліджуючи адміністративно-правові характеристики єдиного медичного простору, автор дійшов думки, що його наповнення залежить від якісної роботи та взаємодії чотирьох складників:

- державної медицини;

- приватної медицини;

- комунальної медицини;

- відомчої медицини.

Двом останнім із перерахованих і присвячена наша публікація.

Коли ми говоримо про відомчу медицину, то передовсім ми маємо на увазі організацію надання медичної допомоги в системі МВС України, Міноборони України, СБУ, Укрзалізниці, Державного управління справами. Тут отримують якісну медичну допомогу особи, котрі мають відношення до вказаних вище відомств, та члени їх сімей.

До прикладу, якщо ми візьмемо систему МВС України, то С.Г. Стеценко та Т.О. Тихомирова зазначають, що реалії організаційно-штатної побудови органів внутрішніх справ України наочно свідчать про наявність тут проблем доступності медичної допомоги. Адже одна справа, коли працівник міліції проходить службу в м. Києві чи обласному центрі і зовсім інша, коли йдеться про сільського дільничного інспектора міліції, котрий забезпечує виконання покладених на нього функцій у декількох селах, жодний із яких нерідко не має фельдшерсько-акушерського пункту. Думається, що тут необхідно виходити як з реалій цивільної медицини (системи Міністерства охорони 
здоров’я, так і з можливостей відомчої медицини системи Міністерства внутрішніх справ України). Одинізможливих варіантів-проведеннящорічних медичних оглядів у лікувальних закладах обласного рівня відомчої медицини, а у разі невідкладної допомоги (чи амбулаторно-поліклінічної) звернення до найближчого медичного закладу цивільної системи охорони здоров' я [3, с. 34]. Чи не стосовно проявів формування єдиного медичного простору говориться у науковій монографії?

Ми переконані, що кращі досягнення системи медичного забезпечення Міністерства внутрішніх справ повинні і мають бути використані для потреб формування єдиного медичного простору. Також і у контексті взаємодії з комунальними закладами охорони здоров'я. Це передовсім місцевий рівень. Це важливо для пересічних громадян, як відомчої належності, так і середньостатистичних, котрі працюють в офісах, начальних закладах, на заводах та фабриках.

Проте констатуємо наявність й інших поглядів. Варто зазначити, що певні фахівці узагалі заперечують доцільність існування відомчої медицини як такої. Приміром, колишній міністр охорони здоров’я України О. Квіташвілі стверджує, що «водники, академіки, залізничники або шахтаpi, які мають свої лікарні, - такі ж люди, як ми з вами. Можливо, специфіка роботи цих установ трохи інша. Можливо, там трохи інша специфіка захворювань, проте загалом люди такі ж, як і ми, 3 тією ж статурою і набором захворювань. Неможливо, щоб в країні паралельно існували чотири або п'ять систем охорони здоров'я, які працюють по-різному. Природно, всю цю систему з відомчими лікарнями можна зберегти в тому вигляді, в якому вона є. Однак вони повинні працювати за тим же принципом, що і решта лікарень. Єдине, виходячи з того, що в країні війна, я б зробив виняток для військової системи охорони здоров'я, силових структур. Там і система працює по-іншому, і зовсім інша специфіка реакцій на кризові випадки [4]. Як бачимо, тільки медичній службі Міністерства оборони України колишній керівник профільного медичного міністерства надає «право на життя» поза управлінським впливом Міністерства охорони здоров'я України.

Що стосується другої ланки взаємодії - комунальної медицини та відповідних лікувально-профілактичних закладів, то, на переконання автора, важливість дослідження проблематики комунальних закладів охорони здоров'я у контексті адміністративно-правового забезпечення єдиного медичного простору пов'язані із багатьма факторами, ключовими із яких можуть вважатись:

- по-перше, ці медичні заклади із позицій організації та надання медичної допомоги є максимально наближеними до пацієнта (сільська місцевість, районний рівень надання медичної допомоги, міські медичні заклади зазвичай знаходяться у власності територіальних громад);

- по-друге, процеси децентралізації, що наразі відбуваються в Україні, засвідчують все більший акцент держави на те, щоб максимально передати надання всіх соціальних послуг (в тому числі і медичних) на рівень місцевого самоврядування;

- по-третє, проводячи аналогію із відомим висловом, який констатує сильну державу за наявності сильних територіальних громад, автор дозволить собі пропозицію того, що сильний та ефективно функціонуючий єдиний медичний простір є можливим за умови сильної комунальної охорони здоров'я та ефективно працюючих комунальних закладів охорони здоров' я.

«Медична конституція» нашої держави, Основи законодавства України про охорону здоров'я громадян у статті 16 констатує [5], що 3 метою забезпечення територіальної доступності якісної медичної допомоги населенню створюється госпітальний округ. Госпітальний округ - це сукупність закладів охорони здоров'я та фізичних осіб - підприємців, які зареєстровані в установленому законом порядку та одержали ліцензію на право провадження господарської діяльності з медичної практики, що забезпечують медичне обслуговування населення відповідної території. $\mathrm{y}$ межах госпітального округу визначаються опорні заклади охорони здоров'я. Порядок створення госпітальних округів та перелік опорних закладів охорони здоров'я затверджуються Кабінетом Міністрів України.

3 погляду проблематики наукового дослідження варто окремо вказати на госпітальні округи та їх адміністративно-правове забезпечення. Скажемо прямо: ця ідея далеко не відразу знайшла позитивний відгук у мешканців сіл та міст України. Цей задум є нереалізованим і понині. Причинами, які стали на заваді цьому, можуть бути вказані такі:

глобальні прояви недовіри громадян до реформування як явища, за яким нерідко криється погіршення стану справ із об'єктом реформування;

- значний ступінь соціальної важливості медицини та можливості отримання доступної та якісної медичної допомоги для пересічного громадянина нашої держави;

- «сильні» та «слабкі» госпітальні округи потенційно роблять неоднаковою доступність та якість медичної допомоги для пацієнтів, що знаходяться у межах різних госпітальних округів;

- різний ступінь матеріально-технічного оснащення госпітальних округів та складнощі щодо проведення їх уніфікації;

- різна територіальна доступність до опорних закладів охорони здоров'я у межах госпітального округу; 
- пересічні громадяни, особливо особи похилого віку, вельми хворобливо переносять зміну звичних умов та місць отримання медичної допомоги.

Демократична, правова, соціальна, європейська Україна - це сильні регіони з розвиненою муніципальною владою, яка відповідає потребам і запитам людей певної адміністративно-територіальної одиниці, покликана оперативно вирішувати питання місцевого значення, ураховуючи комплекс особливостей певного регіону. Саме із цією метою відбуваються децентралізація публічної влади, зміцнення фінансового та матеріального підгрунтя місцевого самоврядування, добровільне об'єднання територіальних громад, розвиток їхньої соціально-економічної інфраструктури тощо [6, с. 85]. У цьому сенсі додамо, що, на нашу думку, належна організація та правове забезпечення діяльності комунальних закладів охорони здоров’я, комунальних закладів організації та управління надання медичною допомогою - це питання місцевого значення, які, однак, характеризуються глобальними соціальними наслідками як для жителів конкретних територіальних громад, так і для всього суспільства та держави.

Багато відомств (Міноборони, МВС, Укрзалізниця тощо) мають свої лікувально-профілактичні заклади саме на місцевому рівні. Це зумовлює, серед іншого, можливість їх активного залучення у межах єдиного медичного простору до надання медичної допомоги місцевим жителям, котрі до того могли отримувати медичну допомогу лише у відповідних комунальних закладах. Серед інших позитивів це також забезпечить фактичну реалізацію права на вибір лікаря.

$€$ ще одна важлива обставина, на яку з позицій адміністративно-правового забезпечення варто звернути увагу. 3 метою якісного залучення та використання потенціалу комунальної охорони здоров'я важливим є вирішення питань належної взаємодії відомчих та комунальних органів управління системою охорони здоров'я. Адже у цьому смислі ми не маємо нехтувати відомою конструкцією, відповідно до якої суб'єктам владних повноважень (а комунальні органи управління медичною сферою, як і відомчі, до них також належать) «заборонено все, що прямо не дозволено законом» . Відтак важливо акцентувати увагу на виробленні на нормативно-правовому рівні тих засад, які слугуватимуть підгрунтям для подальших системних кроків, спрямованих на створення та якісне і належне функціонування єдиного медичного простору із логічним включенням туди комунальної та відомчої системи охорони здоров'я.

Н.В. Шевчук справедливо зазначає, що під суб'єктами публічного управління охороною здоров'я на регіональному рівні необхідно розуміти органи, установи та посадових осіб, які відповідно до вимог чинного законодавства мають владні повноваження щодо здійснення організації охорони здоров'я та безпосереднього надання медичної допомоги на рівні регіону. Говорячи про регіони, зазначений автор має на увазі рівень області та району [7, с. 81].

Ще одним аргументом на користь доцільності можливого залучення комунальної медицини до єдиного медичного простору є потенційне підвищення якості медичної допомоги. Наразі у державі ведуться активні розмови та експертні дискусії 3 приводу запровадження обов'язкового медичного страхування. Це правильно загалом і з позицій формування єдиного медичного простору зокрема. Саме тому слушною є позиція В.Ю. Стеценко, яка, аналізуючи доцільність законодавчого запровадження такого виду страхування в Україні, задається питанням: «Чому ми вважаємо, що обов'язкове медичне страхування є суттєвим кроком до вирішення багатьох проблем української медицини?». I, серед іншого, зазначає про важливі аргументи. Це дозволить забезпечити якість медичної допомоги - об'єктивний критерій задоволеності наданими медичними послугами з боку пацієнтів, а також робитиме реальними правові відносини, які виникають між лікувальною установою, де надавалась медична допомога, та страховою медичною організацією, яка фінансує медичну допомогу. Забезпечення якості та безпеки медичної допомоги має стати індикатором, за яким пересічні громадяни судитимуть про ефективність (неефективність) запровадження обов'язкового медичного страхування [8, с. 50-51].

Підсумовуючи, варто вказати, що саме від держави, від використання нею можливостей адміністративного права, його потенціалу залежить реальний запуск та функціонування єдиного медичного простору. Це альфа та омега медичної реформи. Без доступної та якісної медичної допомоги, без права на вибір лікаря та його реальне забезпечення медична реформа не відбудеться. I ми знову будемо чекати нової реформи.

\section{Jimepamypa}

1. Стеценко С.Г. Предмет адміністративного права як «вічнозелений» сюжет адміністративно-правової науки. Право України. 2019. №5. С. 29-45.

2. Сіделковський О.Л. Єдиний медичний простір як об'єкт адміністративно-правової науки. Публічне право. 2018. № 4. С. 123-128.

3. Стеценко С.Г., Тихомирова Т.О. Медичне право України (правове забезпечення відомчої медицини MBC України) : монографія. Київ : Атіка, 2010. 152 с.

4. Квіташвілі 0. Стандартизація за ліжко-місцем - це зло і шкідництво. Еконолічна правда. 2015. 30 січ. URL: http://www.epravda.com.ua/publicatio ns $/ 2015 / 01 / 30 / 525533 /$.

5. Основи законодавства України про охорону здоров’я. Відомості Верховної Ради України. 1993. № 4. ст. 19.

6. Демиденко В.О. Система муніципального права. Науковий вісник Наиіональної академії внутрішніх справ. 2018. № 2. С. 84-95 
7. Шевчук Н.В. Адміністративно-правове регулювання організації охорони здоров'я на регіональному рівні : дис. ... канд. юрид. наук : 12.00.07. Київ, 2015. $200 \mathrm{c}$.

8. Стеценко В.Ю. Обов'язкове медичне страхування як крок до вирішення багатьох проблем української медицини: правові засади. Публічне право. 2016. № 3. С. $48-53$.

\section{Анотації}

Сіделковський О. Л. Комунальні та відомчі медичні заклади в системі єдиного медичного простору: невирішені проблеми адміністративно-правового регулювання. - Стаття.

Однією з проблем, що активно обговорюється останнім часом у колах фахівців з охорони здоров'я, медичного права і пересічних громадян, є стан і перспективи розвитку медичної реформи. Про неї дискутують, їі побоюються, від неї багато чого очікують. Важливим наразі є питання всебічного дослідження адміністративно-правових засад проведення медичної реформи.

Ми переконані, що кращі досягнення системи медичного забезпечення Міністерства внутрішніх справ повинні і мають бути використані для потреб формування єдиного медичного простору. Також і у контексті взаємодії з комунальними закладами охорони здоров’я. Це передовсім місцевий рівень. Це важливо для пересічних громадян, як відомчої належності, так і середньостатистичних, котрі працюють в офісах, начальних закладах, на заводах та фабриках.

Що стосується другої ланки взаємодії - комунальної медицини та відповідних лікувально-профілактичних закладів, то, на переконання автора, важливість дослідження проблематики комунальних закладів охорони здоров'я у контексті адміністративно-правового забезпечення єдиного медичного простору пов'язана із багатьма факторами, ключовими із яких можуть вважатись:

- по-перше, ці медичні заклади із позицій організації та надання медичної допомоги є максимально наближеними до пацієнта (сільська місцевість, районний рівень надання медичної допомоги, міські медичні заклади зазвичай знаходяться у власності територіальних громад);

- по-друге, процеси децентралізації, що наразі відбуваються в Україні, засвідчують все більший акцент держави на тому, щоб максимально передати надання всіх соціальних послуг (в тому числі і медичних) на рівень місцевого самоврядування.

Окреслено роль та значення адміністративного та медичного права в цих процесах. Актуалізована увага до проблем впровадження у практику медичної реформи.

Ключові слова: медичне право, адміністративне право, єдиний медичний простір, права пацієнтів, комунальна медицина, відомча медицина.

\section{Summary}

Sidelkovsky O. L. Communal and departmental medical facilities in the single medical space system: unresolved problems of administrative and legal regulation. - Article.

One of the topics discussed recently in the circles of health care professionals, medical law, ordinary citizens is the state and prospects for the development of medical reform. They discuss it, they are afraid of it, they expect a lot from it. An important issue now is the comprehensive study of the administrative and legal framework for medical reform. The article deals with the issue of involvement of municipal and departmental health care institutions in the functioning of a single medical law.

We are convinced that the best achievements of the Ministry of the Interior's health care system should and should be used to create a single medical space. Also in the context of engagement with public health facilities. This is primarily local. This is important for ordinary citizens. Both departmental and average, who work in offices, primary schools, factories and factories.

Concerning the second link of interaction - communal medicine and corresponding medical-preventive establishments. According to the author, the importance of investigating the problems of communal healthcare facilities in the context of the administrative and legal provision of a single medical space are related to many factors, which may be considered as key:

- first, these medical institutions, from the point of view of organization and delivery of medical care, are as close as possible to the patient (rural area, district level of medical care, urban medical facilities are usually owned by territorial communities);

- secondly, the processes of decentralization currently taking place in Ukraine show the increasing emphasis of the state on maximizing the delivery of all social services (including medical services) to the level of local selfgovernment.

The role and importance of administrative and medical law in these processes are outlined. Attention to the problems of implementation in practice of medical reform has been intensified.

Key words: medical law, administrative law, common medical space, patients' rights, communal medicine, departmental medicine. 